Удк 343.8

Колб I. О.,

кандидат юридичних наук,

начальник відділу нагляду за додержанням

законів при виконанні кримінальних

покарань прокуратури Київської області

\title{
ПРОФІЛАКТИКА УСУНЕННЯ, ЗАХИСТУ ТА ВІДВЕРНЕННЯ У МЕХАНІЗМІ ЗАПОБІГАННЯ ЗЛОЧИНАМ, ЩО ВЧИНЯЮТЬСЯ У ЗВ'ЯЗКУ ІЗ ЗАСТОСУВАННЯМ СИЛИ ДО ЗАСУДЖЕНИХ
}

3'ясовано сутність і зміст діяльності, що стосується профілактики усунення та відвернення злочинів, які вчиняються персоналом установ виконання покарань при застосуванні фізичної сили, спеціальних засобів і зброї до засуджених, позбавлених волі, а також розроблено науково обгрунтовані заходи щодо усунення існуючих на практиці проблем.

Ключові слова: профілактика усунення, злочин, засуджений, персонал установ виконання покарань, застосування сили, сфера виконання покарань, запобігання злочинам, захист, відвернення.

Выяснено сущность и содержание деятельности, касающейся профилактики устранения и предотвращения преступлений, совершаемых персоналом учреждений исполнения наказаний в связи с применением физической силы, специальных средств и оружия к осужденным, лишенным свободы, а также разработано научно обоснованные мероприятия по устранению существующих на практике проблем.

Ключевые слова: профилактика устранения, преступление, осужденный, персонал учреждений исполнения наказаний, применения силы, сфера исполнения наказаний, предотвращение преступлений, защита, недопущение.

Постановка проблеми. Відповідно до вимог ст. 106 Кримінальновиконавчого кодексу (КВК) України у визначених законом випадках персонал установ виконання покарань (УВП) може застосовувати до засуджених, позбавлених волі, заходи фізичного впливу, спеціальні засоби та зброю. При цьому, як свідчить практика, не завжди такі дії мають законний характер, а тому нерідко приводять до суспільно небезпечних наслідків, а саме - до перевищення влади або службових повноважень, катувань, службової недбалості тощо, які чинним законом про кримінальну відповідальність визначаються в Україні як злочини. Так, лише 2017 р. питома вага таких суспільно небезпечних та кримінально караних діянь, учинених персоналом УВП, у загальній їх структурі досягла майже 8\% [1].

Постановка завдання. Отже, існує складна прикладна проблема, яка підлягає вирішенню на теоретичному рівні з урахуванням того, що у зв'язку з цим залишається низьким рівень діяльності по забезпеченню зазначених злочинів з боку персоналу УВП. Особливо важливим у цьому 
контексті є з'ясування сутності та змісту так званої профілактики усунення, захисту та відвернення, головним призначенням якої $є$ ліквідація суспільно небезпечних наслідків злочинної діяльності вказаних суб'єктів та нейтралізація детермінант, що спричинили та обумовили вчинення злочинів персоналом УВП.

Саме ці обставини і стали вирішальними при виборі теми даної наукової статті, а також при визначені її головного завдання - розробки науково обгрунтованих заходів щодо удосконалення правового механізму та практики профілактики усунення, захисту та відвернення злочинів, пов'язаних із застосуванням сили до засуджених.

Аналіз останніх досліджень і публікацій. Вивчення наукової літератури засвідчило, що проблематика профілактики усунення, захисту та відвернення в механізмі запобігання злочинам, що вчиняються у зв'язку із застосуванням сили до засуджених, $\epsilon$ предметом постійних теоретичних розробок таких науковців, як І. Г. Богатирьов, О. Г. Колб, В. В. Лопоха, С. Ю. Лукашевич, О. А. Мартиненко, М. В. Тарасов та інших учених. Поряд з цим, ураховуючи низку змін, що внесені в чинне законодавство України з питань кримінально-виконавчої діяльності в останній час (2014-2017рр.), існує об'єктивна необхідність проаналізувати та оцінити їх з точки зору завдань, що стосуються ефективності виконання та відбування покарань в Україні. Саме зазначені обставини обумовили вибір теми цієї статті та її головних змістових елементів.

Виклад основного матеріалу. Виклад основного матеріалу. Як свідчить практика, велику роль та значення у змісті кримінологічної профі- лактики відіграє і профілактика усунення, яка визначає таку діяльність суб'єктів, що послабляє або ліквідує негативні явища та процеси, які активізують злочинні прояви злочинності [2, с. 27]. Останні розрізняються поміж собою залежно від соціального рівня суспільних відносин: від недоліків, зумовлених порушеннями функцій державних органів, господарських суб'єктів, громадських організацій, службових осіб і поведінкою громадян, до криміногенних явищ та процесів, які охоплюють значну частину населення [2, с. 27]. При цьому профілактика усунення має три завдання, вирішення кожного 3 яких повинно привести до ліквідації об'єкта, - усунення, а саме: а) існування і функціонування криміногенних об'єктів; б) зв'язків між ними і особистістю; в) зв'язків між особистістю і ситуацією вчинення злочинів [2, c. 28].

Вирішення зазначених завдань, як доводить у своїх роботах В. В. Голіна, можливе за умови досконалого знання криміногенних об'єктів, їх джерел і зв'язків, механізму дії, «уразливих точок», методів і часу запобіжного впливу, оцінки реально досягнутих результатів тощо. Більш того, компетентні органи повинні максимально конкретизувати суб'єктам профілактики поле їх діяльності, пам'ятати про реальні можливості усунення тих чи інших негативних явищ у певний час, строки їх усунення, які, у свою чергу, повинні визначатися, виходячи 3 характеристики об'єкта та рівня його криміногенності [2, c. 28].

Як свідчить практика, строки бувають: 1) оперативні - ті, що обчислюються, як правило, моментом застосування чи коротким проміжком 
часу; 2) лікувально-профілактичні ті, що визначаються часом лікування індивіда, яке спрямоване на усунення його криміногенних властивостей, аномалій, суспільної небезпечності; 3) адаптаційні - ті, що встановлюються для конкретних осіб (групи осіб) для полегшення реалізації профілактичних заходів і подальшого контролю; 4) соціально-тактичні - ті, що розраховані на такі криміногенні об'єкти, які можуть (за прогнозами) бути усунені протягом виконання комплексного плану (3-5 років); 5) соціально-стратегічні - ті, які припускають усунення криміногенних явищ у перспективі [2, с. 28].

Якщо розглянути зміст заходів профілактики усунення через призму запобіжної діяльності, що здійснюється стосовно персоналу установ виконання покарань, то показовою в цьому сенсі $є$ постанова Кабінету Міністрів України від 18 травня 2016 р. № 348 [3], на підстав якої ліквідовано територіальні органи управління Державної пенітенціарної служби України та, натомість, створено міжтериторіальні органи управління (відповідно 5 замість 25 регіональних управлінь виконання покарань) Міністерства юстиції України.

Здавалося б, оптимістична та раціональна ідея. Проте поспішність (діяльність усупереч адаптованим на практиці строкам реалізації заходів профілактики усунення і відсутність узагалі стратегії реформ та науковообгрунтованої концепції видозміни сфери виконання покарань узагалі) та політичний авантюризм (наприклад, прийняття Верховною Радою України 06.09.2016 p. безглуздого Закону «Савченко» [4], відповідно до якого з місць позбавлення волі (CI30, виправних i виховних колоній та арештних домів) у 2016-2017 pp. звільнено десятки тисяч засуджених до позбавлення волі, які не довели свого виправлення, а також для яких не було створено жодних умов для ресоціалізації, у результаті чого значна їх частина вчинила повторні злочини, за які знову були засуджені до позбавлення волі на певний строк [5].

Інший аспект цієї проблематики полягає в тому, що в результаті так званих «реформ» у сфері кримінально-виконавчої діяльності різко зросла кількість вакансій та виник дефіцит «робочої сили», яка повинна працювати (служити) в установах виконання, а що саме негативне - персонал ДКВС України вперше в історії сучасної України (1991-2017рр.) удався до страйку у зв'язку з різким погіршенням свого соціально-правового, фінансового, матеріально-технічного та іншого забезпечення [6]. I це при тому, що відповідно до вимог ч. 3 ст. 15 Закону України «Про Державну кримінально-виконавчу службу України» персоналу ДКВС України проведення страйків та участь у них заборонені. Показовим у цьому контексті $\epsilon$ i страйк керівників територіальних органів управління, який 2014 р. організував та особисто взяв у ньому участь голова ДПтС України [7].

Водночас на сьогодні створено й оптимістичні та науково обгрунтовані програми, які різною мірою стосуються сфери виконання покарань та, зокрема, діяльності персоналу УВП, а також змістовно відображають сутність профілактики усунення, а саме: «Національна стратегія у сфері прав людини» (2015р.) [8]; «Про Стратегію реформування судоустрою, судочинства та суміжних правових інститутів на 20152020 pр.» (2015 р.) [9]; «Про Страте- 
гію сталого розвитку «Україна $2020 »(2015$ р.) [10] та ін.

Свій ефект і відповідні результати у змісті кримінологічної профілактики, як свідчить практика, мають також заходи профілактики захисту, яку розглядають як сукупність заходів, що здійснюються з метою ліквідації умов, які призводять до злочинних проявів та (опосередковано) антигромадських поглядів [2, с. 3-29]. При цьому, на відміну від профілактики усунення чи обмеження, профілактика захисту має на меті створення достатнього захисту і безпеки людей та речей, а також зовнішні перешкоди на шляху посягання на суспільні цінності [2, с. 29]. До об'єктів профілактичного захисту належать, з одного боку, засоби захисту та збереження держаного та приватного майна; засоби особистого захисту (зброя; спеціальний одяг; технічні пристрої; новітні технології тощо), а з другого правосвідомість потенційних злочинів [2, с. 29].

Як слушно зауважив 3 цього приводу В. В. Голіна, форми реалізації заходів профілактики захисту відомі та широко використовуються практично з давніх-давен (віконні грати; металеві двері; хитромудрі замки; прилади спостереження та ін.) [2, c. 29]. Але головне, на переконання кримінолога, не в цьому: профілактика захисту як світова стратегія зменшення практичних можливостей злочинних проявів потребує наукового обгрунтування запобіжного впливу на свідомість потенційних злочинців, технічної охорони озброєності суспільства, а також практики уразливості та можливості захисту тих чи інших матеріальних і духовних цінностей від злочинних посягань, використання новітніх засобів їх захисту в різних сферах життя, заінтересованості держави в залученні та впровадженні різних ноу-хау, дослідження доцільності запозичення зарубіжного досвіду профілактики захисту в національному просторі тощо [2, с. 29-30].

Зміст заходів профілактики захисту в контексті запобіжної діяльності, що здійснюється стосовно персоналу установ виконання покарань, можна продемонструвати на прикладі деяких статистичних даних і peзультатів спеціальних наукових досліджень 3 означеної проблематики [11, с. 387-388]. Так, на сьогодні однією із суттєвих умов, що призводять до вчинення злочинів як персоналом УВП, так і засудженими, $є$ неналежне використання технічних засобів нагляду і контролю (наприклад, відеокамер) за засудженими (ст. 103 КВК України), зношеність яких складає в усіх установах покарань майже 50\%, а на деяких відкритих територіях охороняємих зон вони взагалі відсутні $[11$, с. 388]. Це, у свою чергу, дає можливість персоналу УВП встановлювати позаслужбові зв'язки із засудженими, а також передавати для них заборонені предмети і речовини та вести з ними спільно різні злочини $[12$, c. $12-14]$.

Інші прорахунки та недоліки матеріально-технічного забезпечення сфери виконання покарань (понад 90\% наявних в експлуатації систем охорони периметрів та 49,6\% інших інженерно-технічних засобів охорони CI30 та УВП перебувають у незадовільному стані; в установах виконання покарань експлуатуються тільки 30\% сучасних засобів телекомунікації та зв'язку; із 96 спеціальних автомобілів, які використовуються для переміщення засуджених (ст. 88 КВК України), 90\% перебувають в експлуатації 
понад 20 років та потребують капітального ремонту, а деякі підлягають списанню й терміновій заміні $[13$, с. 113]), створюють умови для вчинення таких злочинів з боку персоналу установ виконання покарань, як службова недбалість (ст. 367 КК); перевищення влади або службових повноважень (ст. 365 КК); злочини у сфері обігу наркотичних засобів, психотропних речовин, їх аналогів та прекурсорів (розділ XIII особливої частини КК України) та ін. [11, с. 12-14].

Так загалом виглядає зміст кримінологічної профілактики в запобіганні злочинам, що вчиняються персоналом установ виконання покарань, зокрема із застосуванням сили до засуджених. Поряд із цим, як слушно зробив висновок В. В. Голіна, кримінологічна профілактика злочинності $€$ найбільш складним і разом 3 тим тонким по розробці і виконанню наступальним запобіжним діянням. При цьому, незважаючи на значний інтерес учених і практиків щодо проблеми запобігання злочинам, багато питань її теорії потребують розробки [2, с. 22], що й було враховано при підготовці цієї статті.

Як установлено в ході даного дослідження, свою роль, місце та особливості реалізації при здійсненні заходів спеціально-криміноло-гічного запобігання злочинам має і діяльність $з$ відвернення злочинів, що вчиняються персоналом установ виконання покарань. Під цією діяльністю в науці розуміють специфічний напрям спеціально-кримінологіч-ного запобігання, що складається із сукупності заходів, спрямованих на окремі групи та конкретних осіб, які виношують злочинні наміри, замислюють учинення злочинів i позитивно сприймають злочинний спосіб життя,
3 метою дискредитування злочинної поведінки, добровільної відмови від злочинної мотивації та наміру або продовження злочинної діяльності [14, с. 144]. При цьому всередині зазначеного напряму запобіжної діяльності науковці констатують відмінність між: а) заходами, спрямованими на усунення більш-менш позбавлених індивідуальності криміногенних об'єктів; б) заходами, що вживаються до конкретних осіб, у яких виник, психологічно сформувався і він реально почав матеріалізуватися злочинний намір (мотив) [2, с. 31].

Першу групу заходів з відвернення злочинів умовно можна назвати загальними, тобто такими, що спрямовані на певне коло або групу щодо усунення або нейтралізації їх злочинних намірів, добровільної відмови від злочинної поведінки [2, c. 32].

Друга група - індивідуальне відвернення злочинів - $\epsilon$ специфічним комплексом заходів, які здійснюються різними суб'єктами запобіжної діяльності щодо осіб, про яких достовірно відомо, що вони замислюють вчинення злочинів з метою активного втручання і впливу на свідомість, волю, поведінку, спосіб життя [2, c. 32].

Як у зв'язку з цим зауважив В. В. Голіна, відвернення злочинів має місце тоді, коли злочинна поведінка проходить етап від моменту формування злочинного мотиву до початку виконання злочину [14, с. 144-145]. Виходячи з цього, він розділив заходи запобігання злочинній мотивації на дві групи:

1. Заходи переорієнтації антисуспільної настанови.

До таких заходів, зокрема, належать: а) спеціальні економічні та 
соціально-психологічні програми, які розраховані на те, щоб людина в суспільстві отримувала більш-менш повне задоволення своїх потреб і відмовлялася від злочинних намірів; б) заходи, спрямовані на формування у громадян антикримінальної культури; в) кримінологічна поінформованість населення для його більш тісного співробітництва 3 правоохоронними органами; г) організаційноправові заходи, які підвищують у людей почуття відповідальності та виробляють у них уявлення про допустимі засоби досягнення своїх потреб $[14$, c. 145$]$.

2. Активні контрзаходи запобігання злочинної мотивації: а) заходи переконання; б) заходи різних форм примусу; в) заходи застереження; г) заходи допомоги особам, звільненим 3 місць позбавлення волі [14, c. 145].

Як засвідчило вивчення юридичної літератури, за відверненням злочинів як одним із напрямів запобіжної діяльності у сфері боротьби із злочинністю визнається самостійність і специфічність, оскільки центр цієї роботи переноситься на стадію, коли з'являється умисел та приймається рішення на виконання злочину [15, с. 329]. Крім того, під відведенням злочинів науковці розуміють сукупність видів діяльності, що здійснюється колом суб'єктів запобігання злочинам шляхом розроблення та реалізації цілеспрямованих професійних заходів [2, с. 31].

Якщо розглянути це питання через зміст запобігання злочинам, що вчиняються у зв'язку із застосуванням сили до засуджених, то варто продемонструвати декілька статистичних викладок. Так, лише 2016 р. персоналом УВП допущено 63 випад- ки сну на постах, що не тільки є ознакою злочину, передбаченого ст. 367 КК «Службова недбалість», але й створює умови для вчинення злочинів щодо персоналу установ виконання покарань [12, с. 31]. Зокрема, у цьому ж році мало місце 23 випадки нападу засуджених (13 випадків) та інших осіб на персонал УВП. Крім того, 2016 р. персоналом установ виконання покарань допущено 37 випадків неприбуття на службу [12, с. 31], що також певною мірою знижувало потенціал цих сил у забезпеченні правопорядку в УВП. Усього ж 2016 р. така недбалість у виконанні службових обов'язків персоналом установ виконання покарань призвела до вчинення цими особами 102 злочинів (2015 р. - 111) та 5 (2015 р. - 16) корупційних правопорушень, а також до 58 інших надзвичайних подій 3 участю цих осіб (24 дорожньотранспортні пригоди; 2 смерті, 38 випадків отримання травм і поранень та ін.) [12, с. 12-16].

Усе це свідчить про низький рівень реалізації в діяльності відповідних суб'єктів запобігання злочинам заходів з відвернення злочинів, як на загальному, так і на індивідуальному рівні. Зокрема, 2016 р. (як, власне, у попередні роки (1991-2015 рр. [1, c. 100-111] та 2017 p. [5, с. 2-3]) через прорахунки в роботі тих чи інших служб та посадових осіб УВП засудженими вчинено 298 злочинів (2015 р. - 458), зокрема й ті, що мають безпосереднє відношення до службової недбалості персоналу установ виконання покарань, а саме: 4 втечі 3 місць позбавлення волі (ст. 393 КК) та 16 - з виправних колоній мінімального рівня безпеки з полегшеними умовами (ч. 2 ст. 18 та ст. 138 КВК), а також з дільниць соціальної реабілітації 
(адаптації) (ст. 98, 99 КВК) [12, с. 1]. При цьому до кримінальної відповідальності за службову недбалість, у результаті якої вчинено зазначені злочини, притягнуто менше 10 осіб $[12$, c. 13$]$.

Висновки. Таким чином, слід констатувати, що запобігання злочинам, що вчиняються у зв'язку із застосуванням сили до засуджених - це специфічний різновид суспільної діяльності, функціональний зміст якої полягає у перешкоджанні дії детермінант зазначеної злочинності та іï проявів через обмеження, нейтралізацію, блокування тощо їх впливів на формування у цих осіб злочинної мотивації і поведінки, а також у здійсненні інших запобіжних заходів, спрямованих на випередження, обмеження, усунення, захист та відвернення або припинення злочинів 3 боку вказаних суб’єктів протиправної діяльності.

\section{Список використаних джерел}

1. Дані про Державну кримінально-виконавчу службу України за 2017 рік Міністерство юстиції України : веб-сайт URL: https://minjust.gov.ua (дата звернення: 11.10.2018)

2. Запобігання злочинності (теорія і практика) : навч. посібн. / Голіна В. В. Харків : Нац. юрид. акад. України, 2011.120 с.

3. Про ліквідацію територіальних органів управління Державної пенітенціарної служби та утворення територіальних органів Міністерства юстиції : Постанова Кабінету Міністрів України від 18 травня 2016 р. № 348. Офіційний вісник України. 2016. № 44.

4. Про внесення змін до деяких законодавчих актів України щодо забезпечення виконання кримінальних покарань та реалізації прав засуджених : Закон України від 6 вересня 2016 р. № 1492-VIII. Відомості Верховної Ради України. 2016. № 43. Ст. 736.

5. Про діяльність підрозділів охорони, нагляду та пожежної безпеки установ виконання покарань у 2017 році : інформ. бюл. Міністерство юстиції України. 2018. 39 с.

6. У слідчому ізоляторі Києва бунтує персонал. Вечірній Київ : веб-сайт. URL: https://vechirniykiev.com.uа (дата звернення: 08.09.2018).

7. Голова Державної пенітенціарної служби України вивів на страйк підлеглих. Вечірній Київ : веб-сайт. URL: https://vechirniykiev.com.ua (дата звернення: 08.09.2018).

8. Про затвердження Національної стратегії у сфері прав людини : Указ Президента України від 25.08.2015 року № 501/2015. URL: http://zakon5.rada.gov.ua/laws/show/501/2015 (дата звернення: 10.08.2018).

9. Про Стратегію реформування судоустрою, судочинства та суміжних правових інститутів на 2015-2020 роки : Указ Президента України від 20.05.2015 року № 276/2015. URL: http://zakon4.rada.gov.ua/laws/show/276/2015/paran12\#n12 (дата звернення: 08.08.2018).

10. Про рішення Ради національної безпеки і оборони від 04.03.2016 року «Про Концепцію розвитку сектору безпеки і оборони України» : Указ Президента України від 14.03.2016 року № 92/2016. URL: http://zakon5.rada.gov.ua/laws/show/92/2016 (дата звернення: 06.08.2018).

11. Ліховіцький Я. О. Злочини, що вчиняються персоналом Державної кримінально-виконавчої служби України : кримінологічна характеристика та запобігання : монографія. Луцьк : ПП Іванюк В. П., 2017. 584 с. 
12. Про діяльність підрозділів охорони, нагляду та пожежної безпеки установ виконання покарань у 2016 році : інформ. бюл. Київ : Міністерство юстиції України, 2017. 43 c.

13. Ільницький О. М. Вплив реформування правоохоронних органів та зокрема кримінально-виконавчої служби на стан громадської безпеки в Україні. Актуальні проблеми прав людини, яка перебуває в конфлікті із законом, крізь призму правових реформ : матеріали Міжнар. наук.-практ. конф. (м. Київ, 2 грудня 2016 року). Київ, 2016. С. 111-113.

14. Кримінологія : підручник / за ред. В. В. Голіни, Б. М. Головкіна. Харків : Право, 2014. 440 с.

15. Закалюк А. П. Курс сучасної української кримінології : теорія і практика: [У 3 кн.]. Кн. 1 Теоретичні засади та історія української кримінологічної науки Київ : видавн. дім «Ін Юре», 2007. 424 с.

\author{
I. Kolb, \\ PhD in Law, \\ deputy head of the department for supervision \\ of observance of laws in the execution of \\ criminal penalties of the Prosecutor's Office \\ of the Kiev region
}

\title{
PREVENTION, DEFENSE AND DETENTION PROTECTION IN THE PREVENTION MECHANISM FOR CRIMINAL EXEMPTIONS BY APPLICATION OF POWER TO THE PROTECTED
}

The article clarifies the essence and content of activities related to the prevention of the elimination and prevention of crimes committed by the personnel of the penal institutions in connection with the use of physical force, special means and weapons to the convicts deprived of their liberty, as well as scientifically substantiated measures concerning eliminating existing problems in practice.

In accordance with the requirements of Art. 106 of the Criminal-Executive Code (hereinafter referred to as CRC) of Ukraine, in cases determined by law, the staff of the penal institutions (PRs) have the right to use the measures of physical influence, special means and weapons to the convicts deprived of their liberty. At the same time, as practice shows, such actions are not always legal in nature, and therefore often lead to socially dangerous consequences, namely, the excess of authority or official authority, torture, official negligence, etc., which are established by the law on criminal liability in Ukraine as crimes So, only in 2017 , the share of such socially dangerous and criminal acts committed by the staff of the Department of Human Resource Development, in their overall structure reached almost $8 \%$.

Consequently, there is a complex application problem that is to be solved on a theoretical level, taking into account the fact that the level of activity on ensuring these crimes on the part of the staff of the PI remains low. Particularly important in this context is the elucidation of the essence and content of the so-called prevention of removal, protection and diversion, the main purpose of which is to eliminate the socially dangerous consequences of the criminal activity of the abovementioned sub- 
jects and neutralize the determinants that caused and predetermined the commission of crimes by the personnel of the PI.

It is these circumstances that have become decisive in choosing the topic of this scientific article, as well as determining its main task - the development of scientifically grounded measures to improve the legal mechanism and the practice of preventing the elimination, protection and prevention of crimes related to the use of force against convicts.

Key word: preventive maintenance, crime, condemned, penitentiary personnel, use of force, scope of punishment, crime prevention, protection, prevention.

Надійшла до редакції 11.10.2018 